\title{
DID MANUAL WORKERS WANT INDUSTRIAL WELFARE? CANTEENS, LATRINES AND MASCULINITY ON BRITISH BUILDING SITES 1918-1970
}

\author{
By Nick Hayes
}

Nottingham Trent University

Twentieth century employer welfarism-that "ragbag" of fringe remunerations and non-money wages - has, by and large, been judged pejoratively: damned for being a "sugared pill" sufficiently appealing to steal away workers' class allegiances or so important to them that its threatened denial promoted disciplined workplace conformity. ${ }^{2}$ Perhaps this is to misconstrue the social relationship between employer and employee, welfare and work: arguably a greater balance always existed in paternalistic practices between "coercion" and active "consent". ${ }^{3}$ Critically, however, neither overview sits easily with an alleged, albeit relatively unexplored, worker antipathy to welfarism or indifference to poor working conditions, where primacy was continually afforded to "money wages" and little else. In these terms welfarism, as either a coercive or consensual strategy, was largely misplaced and can best be explained in terms of employers misinterpreting worker priorities. ${ }^{4}$

Yet trade union pressure for welfarism increased through time: indeed, the greater prejudice against giving welfarism a "fair trial" came rather from company directors and managers. ${ }^{5}$ Wrigley notes that when, during the Second World War, joint workplace committees were established in British industry to improve productivity, "as much of as a third of their time was spent on discussing welfare and other matters" - a scenario more suggestive of employer past neglect and worker interest, than coercive imposition. Nor apparently was this simply wartime bonhomie. An analysis of joint consultation foci in the post 1945 period suggests a continuing workplace preoccupation with "tea, towels and toilets"?

Did workers themselves, therefore, want welfarism, and if not, why not? This article tests the attitudes of operatives in the construction industry, from the introduction of national collective bargaining shortly after World War One through to the period of alleged modernization in the 1960s. The views of building operatives offer an interesting pointer because construction was reputed less for its pristine provision than its "primitive" welfare conditions: here perhaps we can find a baseline marker against which attitudes in other industries may be set and judged. Construction was almost exclusively an all male world. Inherent within was a philosophy that placed little productive value on improving working conditions, and instead stressed worker self-reliance. Yet construction operated, too, within an industrial relations system reputed for its capacity "to play fair", 8 where the building unions increasingly demanded reform and a broader industrial-political discourse existed championing the cause to "humanize" British industry.

The article takes as its starting point the construction of a positive masculine site identity, based on skill but also on physical endurance and hardship. 
Welfarism, it will be argued, frequently worked against the operatives' cultural understanding of what site life meant. Union representatives, however, viewed this site life through different filters. Moreover, the socio-industrial constructs of "conditions of work" issues changed through time. Only in such inter-locking contexts (for example, workplace control, status, respectability and toughness) can the negative attitudes of operatives to welfare and fringe benefit provision be understood.

\section{Site identity, manliness and welfare}

The discourse on the building industry as a "Cinderella" sector with poor welfare provision is well established: contextually, the "tough working conditions taken for granted in a coarser nineteenth century world", by the inter-war period "began to look anachronistic". 9 Writing in 1948 the Labour economist, David Hall, characterized this state of affairs as "well known" for being "fairly, sometimes very bad":

Work takes place in the open air, often on remote sites and in bad weather-if it is not stopped altogether, thus leading to the age old curse of the industry, broken time... There are few of the welfare amenities to be found in the modern factory, such as canteen, cleaning and drying facilities ... The work itself is generally physically hard, and the lot of a builder on an exposed site in January, perhaps with his clothes soaked while on the way to the job, is not to be envied. ${ }^{10}$

Perhaps, however, this was a judgement more frequently made by "middle-class onlookers" than by the workers themselves. ${ }^{11}$ Operatives thought construction a "manly" occupation - "in the blood"-instilled with crafts pride and independence. Men (and boys) were attracted by the "spirit of adventure in the industry" and the open-air, healthy lifestyle; and the lack of direct supervision and the job freedom to move easily from site to site. ${ }^{12}$ The unions, likewise, openly admitted to an "age-long tradition of indifference" to welfare needs. ${ }^{13}$ Nor, despite the poor conditions, was there any rush to leave the industry, even during the years of full employment following 1945.

It has been argued of American construction workers that their "manliness was so taken for granted" that it acquired iconic status. ${ }^{14}$ Although this "exaggeration" was less evident in the public persona of British building operatives, nevertheless the self-descriptors captured above encapsulate those key defining elements of "independence, mutuality and pride in craft" that bespoke respectable working-class male identity-where skill, craft and workplace control equated to maleness. ${ }^{15}$ Twentieth-century deskilling and the introduction of female labor, which destabilized such constructs for male manufacturing workers, were noticeably less evident as processes in building. Indeed, the continuing physical nature of construction was, and always remained, a central component of site life. Both skilled and unskilled operatives shared, albeit in differing proportions, a complex identity: a blend of defining "roughness" and "respectability" located within differing melds of physical endurance and skill found within each site occupation. ${ }^{16}$ This self-understanding eschewed a simplistic response to welfare provision as, for example, a method of collectively seeking to minimize insecurity or hardship, or maximize income. Indeed, if we view the construction 
of workplace identity primarily as a defensive mechanism empowering the exclusion of other groupings (both male and female), ${ }^{17}$ then improved welfarism debased the accepted currencies of physical endurance and self-provision central to building worker separateness. Of course, on any site, working conditions tended to improve through the contract as the physical structure itself grew (providing physical shelter, etc.). It has been suggested, thus, that worker attitudes and behavior, in being environmentally led, also became more 'refined'- - that is less rough — as contracts progressed and provisions improved: and implicitly that building operatives responded positively to welfare improvement. ${ }^{18}$ This linkage between attitudes and environment will not be disputed, but rather extended then turned on its head. Building operatives, it will be argued, came to set their own environment: moreover, this environment became a positive product of their self-imagined values and very real preferences.

Workplace male cultures generally helped shape generic attitudes to welfare in and outside of construction: indeed the "spontaneous" response to provision is indicative of the social codes operating. After 1918, for example, there were widespread reports of the wanton destruction by returning male factory workers of the amenities provided for women during the war. Twenty years later, Factory Inspectors still echoed the "deep-rooted idea on the part of management" that new forms of amenities were "not appreciated and used by the majority of workers and in some cases even sadly mis-used or even destroyed"-actions "put down to [male] horse-play." Inspectors had seen similar problems before: "met and overcome in a generation". It was "really a question of education" by trade union leaders and employers. ${ }^{19}$ And the emphasis within codes of behavior did change: the stories told about wanton damage became more exaggerated than factual, and lavatories became territories marked by male factory workers for informal recreation and socialization, semi-detached from the discipline of the shop floor. ${ }^{20}$ Moreover, the promotion of welfare at work acquired popularist overtones, particularly during the Second World War. ${ }^{21}$ Functionally, then, amenities acquired differing meanings for management and workers, factory inspectors and trade union officials: from that of a utilitarian provision linked to productivity to one of a counterpoint focus for workplace male bravado. Welfarism was also more noticeable in those "new" industries distinguished by rapid technological advance-helping "control industrial relations and enforce the acceptance of change". ${ }^{22}$ Gospel notes positively its prevalence before 1939 in those firms with a stable labor force "operating in large and homogeneous markets, employing continuous process-type technologies or ones where continuity of operations was important." (Clearly, as a migratory industry with a frequently bespoke product, construction is far removed from this ideal.) Increasingly, too, welfarism was administered through specialist internal management structures, run by men and paying more attention to male workers. ${ }^{23}$

In the construction industry workplace supervision was notably less overt. Activity-formal and informal - centered on the working gang, frequently consisting of skilled and unskilled workers (for example, a team of two bricklayers with one attendant laborer). Moreover, operatives often moved from site to site together. A marked sense of "social solidarity of the group" existed; its "mainspring seemed to be spontaneous sociability". ${ }^{24}$ It was less that welfare facilities were vandalized-little was provided to damage-than that provision 
was deemed gratuitous. Socially, there were few communal attractions associated with a canvass enclosed "bucket" or "trench" latrine on a rainy or sunny day. ${ }^{25}$ "Unofficial" focal points were anyway less important within the informal structures of site life. Yet a stronger determinant was the shared identity of self-sufficiency associated with the part-nomadic, rugged lifestyle of the building operative. As Willis has observed, "difficult, uncomfortable or dangerous conditions" were reinterpreted positively by workers: "seen, not for themselves, but for their appropriateness to a masculine readiness and hardness"; understood more through "the toughness required to survive them" than as an imposition. Working life and endurance thus became an intrinsic "heroic exercise of manly confrontation". 26

Wartime disjunctures from "normality" aptly illustrate the intertwining, ubiquitous attitudes to welfare provision driven by such masculine self-portraiture. Thus even the pro-reform Factory Inspectorate could readily contrast the archetypal pre-war "British navvy, a sturdy example of the best type of workman, well organised and, typically, well able to look after himself", with his wartime replacement-a "new class of labour not accustomed to the navvy's work and not so able to settle down to rough conditions." 27 This "new" labor was, in fact, significantly older on average, and site conditions notoriously poorer initially than even the spartan environment operating before 1939. It is instructive, therefore, to look briefly at how each side of industry reported this. Among employers, the "progressive view" acknowledged that wartime provision "in remote rural areas had not been altogether satisfactory". And they noted, too, that "nothing would be further removed from the wishes of building operatives than that they should be molly-coddled." 28 Union delegates deplored the employers' failure to provide the agreed "bare necessities" of "better hutting accommodation, canteens, sanitary arrangements, etc." required because geographic dislocation had made operatives less self-sufficient. ${ }^{29}$ Yet as one union commentator admitted shortly after:

It seems strange (or does it?) that many building workers themselves, as well as the more backward of employers, required the evangelising zeal of the propagandist to convince them that they need better conditions than the primitive ones to which they had for so long become to well accustomed. ${ }^{30}$

Twenty years later union representatives still rehearsed homilies suggesting that "Building Trades Craftsmen are self-reliant and prefer to look after themselves." 31 Attitudes to welfarism were thus part of a broader, positive interpretation of the building process as being almost romantically anti-modern, traditionalist and crafts-orientated, and overtly masculine-set within a dominant discourse portraying it as "backwards" when compared to factory-based manufacturing. ${ }^{32}$

\section{Operatives versus unions: who wants holidays or a guaranteed week?}

Even as membership rose rapidly in the 1930s, the building unions "spoke" for only some 450 thousand of the 1.5 million workers in the industry. ${ }^{33}$ Within this body divisions existed between crafts and general unionism; between craftsmen's laborers, general laborers and navvies (where union membership fluctuated wildly); those permanently mobile and those less so. A corresponding difficulty 
could be found in organizing at site level. ${ }^{34}$ As one official reminisced, "an organiser could go into a mess room and nearly choke himself trying to explain to the men their duty". ${ }^{35}$ Barriers existed, thus, between a reformist, moderate leadership, activists (about 20 per cent of the membership took an interest, of whom 10 per cent took an active interest), a lethargic majority, and the mass of unrepresented building workers, who-in any sense-remained unconsulted. Craftsmen constituted a little over half of those working in the industry, although the numbers of semi-skilled workers was also rising significantly. The former provided the "backbone" of the union movement: they had the "weight and staying-power" to determine all basic labor issues. ${ }^{36}$ The linkages between skill, "respectability" and attitudes to welfare provision, however, were less than linear. Firstly, both skilled and unskilled union leaders and delegates vigorously supported reform. Secondly, while it was probable that on site craftsmen were more likely, and unskilled, itinerant laborers less likely, to favor and take advantage of improvements, the defining influence of such constructs as self-sufficiency and "manly" resilience to hardship bridged the skills divide.

It is the central tenet of my argument that the construction industry's attitude to welfare provision was determined primarily by operative preferences and perceptions which were underpinned by a social subscription to the identity of "site life". Sufficient "common understanding" existed, too, for the unions and employers to judge that they also could speak authoritatively on the operatives' behalf. Undoubtedly, this carried with it a tendency to distort and exaggerate operative opinion, married to each's appreciation of its institutional functions and responsibilities: thus trades unions leaders tended to become more zealous advocates of reform than their membership. ${ }^{37}$ Formal changes to the "working rules" governing wages and conditions in construction were bilaterally set through the National Joint Council for the Building Industry (NJCBI), considered by both sides to be the "most effective machinery for industrial relations and industrial negotiation in the country." If warranted, this collective filter for opinion was deemed capable of "extending its functions in many directions"including the provision of fringe benefits and improved welfare-a "mutual approach" motivated by "what is best for the industry." welfare provision-as a humanizing agent-was thought integral to the process of consensus building. ${ }^{39}$ In construction, however, the governing perceptions of site life and identity were frequently to override such institutional dynamics for reform.

Where were the attitudinal limits of this welfare separateness? In an industry as heavily casualized as construction, it is not surprising to find that a very real preoccupation existed with money wages. Indeed in industry generally even high profile campaigns-like that of the Trades Union Congress's promotion of holidays with pay between the wars-could still be sublimated by the priority of wages. Moreover, holiday pay was deemed important by unions precisely because of the "hardships associated with the unfinanced break from work." Like many other fringe benefits, therefore, it was contextually linked to wage setting. Nevertheless through time welfarism also acquired the broader persona nationally of being a socio-political "right" to be demanded, rather than being an employerinitiated "gift". ${ }^{40}$ As Jones argues, the authority of the holiday's campaign came because it unified and "captured the imagination of millions of trade unionists," 
their families and Labour Party supporters in a way impossible for a similar stance over wages, where interests remained "sectional and disjointed." 41

Were construction workers located inside or outside this aggregated trend? The building unions certainly offered important and continuing support to the holiday's campaign. This despite a joint judgment by unions and contractors that employment patterns-the lack of continuity, its seasonal nature, the frequent changing of employers-made problems of application "very serious indeed". 42 The major and correlated problem, the unions thought, lay in

educating our own people to demand holidays with pay ... because some of our people were casually employed we had got into the habit of ignoring this.... We had got to get that feeling into our own members' minds and then there would be no difficulty with the employers. First of all we had to organise our own opinion.... some building workers and others were so fond of their work that they would not take a holiday even with pay, but most of them would be better for the change. ${ }^{43}$

There were, in fact, "innumerable schemes" already operating overseas covering construction, and in other industries within Britain where workers were not employed permanently with one firm. ${ }^{44}$ The case for structural impracticality, therefore, needs to be subjugated to that of an impotence primarily born of operative apathy. Union representatives, however, determined to turn this around. As one conference delegate asserted anecdotally, there was "a growing demand amongst the workers in our industry for this." Such a discourse continually overshadowed those few who questioned "if we were not wasting our time and money on people whom we had not got with us on this.... it was idealistic," and open to abuse. ${ }^{45}$

The NJCBI remained justifiably concerned lest others working in the industry simply ignored national agreements promoting welfarism and undercut labor costs. ${ }^{46}$ Nevertheless, it agreed to promote the "landmark" introduction of paid holidays in $1943 .{ }^{47}$ Can we better quantify the mood on site by examining subsequent events? Certainly the post-war history of the scheme was one of continuing advance in terms of participating numbers and gains. However, this tells only part of the story. Many employers and workers presumed that the holiday credits issued by way of weekly stamps could be cashed irrespective of whether or not operatives took their holiday. Thus credits were commonly viewed "merely as an additional remuneration." ${ }^{48}$ Ten years later an acknowledged problem remained of those "who prefer the pay to the holiday": that is money in the pocket rather than time away with the family. A more active expression of "manly resistance" was the wide-scale, illegal trafficking in holiday stamps. There were "places established where you can go and sell stamps and make a profit. The man has his runners on the job." One defendant, testifying in a fraud case, claimed to be able to "buy 1,000 cards in an hour." Cards sold for a quarter or half their value, reported the national administering manager of the holiday scheme. Operatives were "selling $£ 8$ or $£ 9$ cards for a mere $£ 1$, perhaps to get an extra drink," or cashing them in through a bookmaker. ${ }^{49}$ Yet union representatives pressed for greater entitlement, arguing that-as in other welfare areas-construction, comparatively, continually lagged behind other industries. For some, however, this deficit remained the embodiment of construction's masculine site culture. As one union delegate commented, when faced with the prospect of additional 
holiday: "Can you imagine, for one moment, what pleasure there is going to be for the building trade operative, having had a fairly decent Christmas, to have to spend ... three to four days [extra] inside their house with their wives?"50

Disparities between site and national values are central to an understanding of attitudes to welfarism. Yet there was one key fringe benefit where, because it related directly and beneficially to money income and improved status, little disagreement should have been evident. The "history of the struggle of the Building Trade operatives over the years," one union delegate remarked in 1964, "was consistently one of trying to avoid the hardships of casualisation." Even building workers, apparently, balked at encouraging their sons to enter the industry because employment was "too insecure". Yet insecurity was also a mirror image of that which operatives valued most highly: the freedom and variety inherent in construction where workers transferred easily between sites. A guaranteed week, therefore, and, with it, protection from immediate dismissal with the onset of bad weather, also meant offering employers a corresponding notice to quit which the majority of operatives-although not union leaders-strongly opposed. ${ }^{51}$ In common, for example, with dock workers, the habits and beliefs of each industry's "culture of work" became "inseparable from the casual nature of employment." While external commentators frequently lamented the inequities of this system, curtailing a worker's compensating "own [positive] conception of 'freedom'" struck at a central tenet of his affirmative identity: his perhaps idealized ability to choose when, where and on what worked, upon which sense of workplace control his skilled status and masculine identity were grounded. ${ }^{52}$ Thus, those aspects of decasualization that led to even marginal increases in the powers and prerogatives of employers were strongly resisted.

Nevertheless, post-war researchers concluded from workplace surveys that, when combined with the social "stigma of casual labour":

the assurance of greater security and a guaranteed week seem a matter of urgent importance to building operatives. To operatives there was no comparison between the value of a steady guaranteed wage and the value of higher but less regular wages. ${ }^{53}$

This ignored earlier experiences. Negotiating payments for time lost through inclement weather had a checkered history stretching back into the nineteenth century. The settlement of the 1924 national building dispute called for a resolution of this question. However, it was not until union negotiators accepted the principle that employees, too, contribute to the cost that agreement was reached with employers. ${ }^{54}$ Because the scheme needed to be made statutorily compulsory, and contributions levied, each membership had to be consulted. The National Federation of Building Trade Operatives (NFBTO) held its ballot in 1938. In the terms outlined, the outcome should have been clear cut:

it is obvious that our people will not tolerate the terrible conditions which they have been compelled to endure in the past, ... that if they ceased work they were compelled to suffer financial loss.... in addition to the scheme enhancing their economic position, they would not be forced to subject themselves to the vagaries of the elements, ... and in consequence many of the distressing illnesses from which they have suffered ... will be avoided. ${ }^{55}$ 
In fact the vote was easily carried: 82,669 for the scheme and 49,417 against (a majority of 33,252 ). Those who were the most likely beneficiaries-bricklayers, painters, laborers - voted heavily in favor. However, those who worked mainly inside - the carpenters and woodworkers, plumbers, plasterers-all voted against by a clear majority. Outcomes were thus determined directly by partial evaluations of cost, reward and control, rather than through a shared mission of improvement to end insecurity, or according to a dichotomous division determined by skill and standing.

The voting figures, however, warrant further evaluation. Ballots were cast by a little under fifty per cent of all paid up members. Given the problems of geographic scatter associated with construction work, clearly this was deemed an important issue ${ }^{56}$ The vote, for example, in the Amalgamated Union of Building Trades Workers (representing the trowel trades) "was the biggest it had every managed to record on any question in its history", at around sixty per cent. All but one union balloted its members. The exception was the Transport and General Workers Union, whose decisive 30,200 bloc vote was cast for acceptance according to area conference decisions: a methodology described by opponents as being akin to "jerrymandering", but justified because officials claimed a 'knowing' of their members and 'their desire'. 57

Participatory rates in laborer's unions were consistently lower than for craft unions. ${ }^{58} \mathrm{Had}$ the T \& GW followed the procedures of its peers, pro-rata with the other main general building union fewer than 5,300 votes would likely have been cast (in the ratio 6:4 favoring wet time insurance). This most comprehensive test of inter-war views on fringe-benefits thus reveals site opinion to be finely balanced even on that issue most directly related to earnings. It is true, of course, that the objection to wet time payments rested principally with the employers' demand that operatives contribute towards the cost (to the detriment especially of the poorer paid laborers whose leadership nevertheless was the most determined that it be adopted). Nevertheless, that objections were raised seriously disturbed the NFBTO leadership:

One would have thought, also, that generations of experience of the curse of Wet Time would have ingrained in all building workers such a loathing of it that the demand for the Scheme would not merely have been unanimous but clamant, vociferous. The most tragic people in all the world are those who oppose their own betterment. ${ }^{59}$

Wet time payment was further delayed by the number of objections from individual operatives, trade union branches and employers, and then by the outbreak of war. ${ }^{60}$ It was finally introduced on government wartime contracts on a noncontributory basis. Subsequently it became subsumed into the wage-bargaining process, but remained closely tied, too, to operative perceptions of limiting managerial prerogatives on site.

\section{Humanizing construction, perhaps, but there's "something cissy about safety"}

It would be a mistake to assume that attitudes to fringe benefits or welfare ran constant through time or by issue. One union official perhaps caught one such 
moment of change when explaining, shortly after the Second World War, why standards in the industry were "so poor":

Is it because we have striven to secure a higher standard of physical amenities and failed because of the employers' opposition, or is it because of our own failure to define our conception of what should be done to alleviate the harsh physical circumstances that surround our work-a-day life? The fault lies principally at our own door. Our efforts over the years have been directed primarily towards wages ... Comparisons are often made, wrongly in my view, between our industry and others, and the plea is made that because we are not static, but are continually moving here, there and everywhere, it is impossible to expect much change. That attitude of mind largely explains past failures. We have underestimated our human value.... if we had fixed standards and attention to human requirements, they would be an integral part of the industry, and wherever the unit of industry was located, they would be put into operation. ${ }^{61}$

Adopting the "hair-shirt" of responsibility became union officials because of their past neglect, and because of their own perceptions of how change came about. Such testimony, however, too readily attributes to the unions an authority which lay beyond their powers as educators and advocates to impose, for their memberships had strongly earthed precepts of what did and did not constitute social site identity.

Nevertheless immediately after 1945 a congruence of forces existed to press the modernizing discourse of change. How did site opinion react to such favorable portents to reform? Certainly new benchmarks for provision had been set. Direct government intervention during the war "resulted in a remarkable improvement in the standards of welfare on sites." ${ }^{2}$ Those wartime sites with "bad" (which by peacetime standards meant almost intolerable) welfare conditions had "considerable difficulties" in recruiting and "preventing men from leaving". Subsequent improvements here met with operatives' approval. Employers representatives, too, apparently accepted that "we must never go back to ... [those] 'uncivilised standards of former days.' "633 These new standards were voluntarily embraced into a Code of Welfare by the industry in 1948. Yet how widely these were adopted on site remains disputed. Despite "some evidence of instances where the arrangements for welfare have fallen short of what it required," one bilateral committee of enquiry concluded, standards generally "appear to be regarded as reasonable and adequate." Union officials, however, stressed that the code was "insufficient in itself"- and anyway "it is not kept." 64

If employers after the war were more readily embracing the "humanizing" supply-side practices of welfare/efficiency linkages, it was primarily because they were regurgitating attitudes presented by government, academics and various official enquiries - stimulated by the dramatic decline in war and post-war building productivity levels-rather than responding directly to operative demands. Appeals to self-interest also helped. Before the war, unemployment in construction remained high; employment was frequently casual, short-term and seasonal. ${ }^{65}$ But "Under conditions of full employment," it was argued:

the standards of welfare may well have a considerable bearing on an employer's ability to retain his men, and on the degree to which labour may tend to seek 
employment in the industry. The importance of welfare facilities as one means of increasing production cannot therefore be overlooked. ${ }^{66}$

Similar stress was placed on the need for positive incentives: the dialogue of partnership between management and operatives, and "the value of good working conditions." Financial incentives alone, it was being suggested, were insufficient. ${ }^{67}$ It would be unwise, however, to be automatically distracted by a national discourse favoring improvement. On site such Damascene conversions were noticeably less apparent. Management remained skeptical about the value of formal joint site productivity committees precisely because of the latter's preoccupation with welfare issues. Here, not only was welfare provision deemed to be unrelated directly to productivity issues, but those workers' representatives calling for it were labeled political extremists. ${ }^{68}$

Indeed the presence of a head-quarters centric "progressive" ambiance radiating welfare demands needs to be grounded against the more pervasive history of non-provision which guided the day to day realities of site culture and worker expectation. In other "non-progressive" industries-for example cotton and pottery-welfarism as a belief system had established roots; albeit that a paternalism based on benevolence and obligation were giving way to welfarism as a promoter of "rational efficiency". ${ }^{69}$ Building and civil engineering historically remained outside this cultural tradition of employer provision. State regulation, too, remained limited, even in such basic areas as safety and sanitary codes. Admittedly, construction was not on its own in this respect. Yet, not withstanding the 1937 Factory Act, it was only after the Second World War that legislation defined what was deemed "sufficient or suitable" welfare provision for building and civil engineering operations. ${ }^{70}$

Benchmarking, however, was essential if site, and thus operative, interest and expectation were to be stimulated. Construction, for example, had one of the highest accident and fatality rates of all industries. During the inter-war years only the increased use of powered machinery drew it partially under the authority of the Factory Inspectorate (sites without mechanical power, irrespective of risk to operatives, remained excluded). Civil engineering contracts, which included such projects as power stations, in that such works were not regarded legally as "buildings", remained outside of covering legislation until 1961. Yet it was not unknown for local union officials to contrive to recategorize building projects as ones of civil engineering precisely because the latter had fewer restrictions governing employment practices. ${ }^{71}$ This was part of a broader culture-setting a antipathetic benchmark - of securing extra payment for tasks involving additional risk that was integral to the industry's structure. ${ }^{72}$ "In the past years, we have spent many hours ... talking of pennies and tuppences in relation to the hazards that men undertake in their employment," conceded a union official in 1956: this "is not the way to remove the dangers inherent in the industry." Nor was it simply that trade-offs were part of the formal negotiating process at a national level. On site, too, card [shop] stewards, even on well-organized jobs, continued to condone unsafe practices "in return for negotiating a danger-money plus rate." As in other industries, many workers- "including good keen trade unionists"- took unnecessary, "stupid" risks, inured to the danger. To do otherwise ran counter to "observed" everyday custom and practice. Indeed, it might 
be considered "unmanly or soft". Within the "cult of toughness" that pervaded industrial life, industries and occupations were instinctively graded according to how masculine they were, and workers and managers identified with, and constantly sought to prove themselves against, such social constructs. In building, even model employers considered many safety provisions to be "unnecessary pampering to a hardy breed of men." Many operatives, too, thought there was "something cissy about safety and fancy themselves as tough guys," union officials acknowledged. Culturally and economically, therefore: "Our lads are not just a set of hard-done-by innocents when it comes to safety." ${ }^{174}$ Instead they ignored regulations to save time- "egged on by the incentive of extra bonuses"-placing the "pay packet" and cultural conformity above personal safety. ${ }^{75}$

\section{Workplace control and conditions of work}

The absence of statutory regulation and paternalistic provision in construction meant, ironically, that the only traditions available to stimulate worker demand for welfare had to be home cultivated. And, despite pre 1939 laxities, there were precedents to draw upon. Price argues that in the nineteenth century, "conditions of work" issues were consistently pressed by building unions when they felt able to push forward the frontier of workplace control. As trade improved in the 1890s, the once structurally predominant Operatives Stonemasons struck not only to press wage demands but also over questions like meal hours and the provision of covered working areas. ${ }^{76}$ Thus central to the nineteenth century construct of workplace control for skilled building workers, and thus ultimately to their perceptions of manly independence and respectability, ${ }^{77}$ was a superstructure of welfare concerns directly linked to status which only later came to be regarded as increasingly marginal to an operative's affirmative "site life" identity. Indeed, traditionally for building trades unions the "paramount question" had "always been the 'working rules'"- agreed individually between crafts and local employers - that included rates of pay and the provision of mess halls, grinding time and tea-breaks, etc., for key individual trades. ${ }^{78}$

Yet if we judge "value" by its continuing inclusion in such agreements, welfare provision remained a basic necessity through into the inter-war period of national collective bargaining (with its preoccupation with wages and hours). Most Regional Working Rules prescribed for welfare facilities. That for the London area, for example, called for the provision of mess rooms, with a laborer in attendance to cook hot meals. By the late thirties, it also called for sanitary accommodation. The Worthing district rules always included either for the provision of a lavatory on sites of a "substantial nature", or "out-of-pocket expenses" in lieu for the use of public conveniences. ${ }^{79}$ Yet as predicators of worker fealty to the cultural priorities of welfare, and as an expression of a workers' status and ability to govern independently his working environment, most lacked veracity or force. Nearly all included caveats actively limiting the obligations on employers to provide facilities only on larger contracts. The unions acknowledged that they had "never been able to get the employers generally to interpret that provision." ${ }^{80}$ Defining practicability and reasonableness, therefore, remained primarily an employer prerogative-which was why union leaders thought precise statutory regulation was essential. 
In part, at least, the disparity between nineteenth and twentieth century robustness in prosecuting "conditions of work" issues reflected the declining focus on local union activity, where branch and thus site representation counted for less under a national system of bargaining. ${ }^{81}$ Interestingly it was the Liverpool area, noted for its labor militancy and higher wages structure, which stayed outside the national agreement until 1945, that operated the most welfare progressive "working rules". Exceptionally this demanded sanitary provision on all jobs, and included for a disputes procedure to arbitrate over whether or not the scale of a contract warranted mess-hall and other provision. Liverpool was also operating its own holidays with pay system prior to the national scheme being introduced ${ }^{82}$ Generally, however, union activity focused on battling to protect money wages, and, albeit unsuccessfully, on those welfare measures that would restrict the labor supply in the market (for example, paid holidays, pensions and early retirement) in an attempt to mitigate the impact of high unemployment. ${ }^{83}$ Thus the interwar period did not see an end to union attempts to control workplace activity: epitomized in the resistance to "payments by results" rather than plain time rates, but also in guarding existing working territory, crafts status and privilege. ${ }^{84} \mathrm{It}$ was the case, however, that "conditions of work" issues took a lower immediate priority as an exemplar of control.

\section{Interpreting self-identity: masculinity, respectability and roughness}

In seeking to explain why the skilled building operative's self-identity changed noticeably between the late nineteenth and twentieth centuries, from a focus on "respectability" to one of "machismo", authority has been granted to broader exogenous changes imported from society and the industrial system: particularly the impact of automation and deskilling on workplace control and identity ${ }^{85}$ The resultant "crisis of masculinity", exacerbated by male unemployment and rising female employment during the inter-war years, is said to have engineered a reconstructed generic maleness exemplified positively through the idioms of strength and the ability to endure harsh conditions, and through the negative imaging of the feminine. ${ }^{86}$ While such active descriptors can be readily ascribed to construction workers, illuminating their responses to welfarism, doubts remain as to how far patterns of workplace activity elsewhere imposed themselves upon construction. As already noted, the labor process in building was consistently dependent - from the nineteenth into the twentieth century-on the attributes of physical skill, strength and endurance. Thus if changing values within society help explain how the industry was viewed from outside, they say less, directly, about how identity was discerned internally. Perhaps, indeed, it is to the anachronisms of poor physical conditions-improving in other industries but not in construction - to which we should first look when seeking to explain why roughness and respectability merged to become a shared identity on site across skills levels.

Everday familiarity, of course, depended not only on physical experience or collective memory, but also on contemporary narratives about what was possible, or warranted, or indeed desirable and compatible with site lifestyle. Responses to such criteria could be contradictory. Despite a strongly positive affirmation to the manly virtues of site life (independence, variety, etc.) just under half of operatives 
asked in 1946 opposed their sons entering the industry, and many more remained doubtful (which, set against the degree of job satisfaction evident, was high when measured against working-class parental aspirational levels generally). The main reasons given were lack of job security, low social status and poor working conditions: indeed, "discontent about many aspects of the working environment (such as wages, lack of canteens, etc.) was far more intense and widespread" than initially thought. ${ }^{87}$ Complaining about the lack of washing facilities, one bricklayer testified:

the men try to get clean in the afternoon.... We all bring a brush to work for our boots and clothes. It makes you feel bad to sit in a bus in dirty clothes and have the person next to you give you a look and then move to another seat.... Why should it have to be that way ${ }^{88}$

This uncertainty extended to a disbelief that conditions were likely to improve. Such shortcomings directly addressed a perceived lack of status within the broader community. Thus, while the spirit of self-reliance was central to "site mentality", for skilled tradesmen particularly, social standing was also important: not just formally on site where it was prescribed in working practices and a crafts pride in skill, but beyond. ${ }^{89}$ As one union delegate observed, "it was time our people had the facilities on the job for washing themselves and changing into other garments so that when they left work they could mix with the rest of the community. At the moment they felt that they did not 'belong'-that they were the 'great unwashed.' "90

The absence of welfare consciousness-highlighted by the acceptance and cultural elevation of "rough" site practice-thus ran parallel to discourses of traditional self-independence but counter to sentiments extolling the still important "respectable" public status of skilled operatives. This became particularly evident at times when the industry was fixed in the national spotlight but also held in low esteem: for example, during the housing crisis immediately after the Second World War. Debating the lack of site canteen facilities, it was argued: "We have watched the erection of vast sheds to protect cement and building materials, while operatives had to squat on upturned drain pipes. We had eaten our food in cement sheds and we have never claimed from employers that human dignity to which we are entitled as workers. ${ }^{" 91}$ Nevertheless, even on those sites where "the most elaborate arrangements had been made for feeding," union officials "were struck" still by the intrinsically conservative "attitude of the men" to accepting progressive improvement. ${ }^{92}$ Generally the Ministry of Labour advised contractors to plan canteen provision on the basis of only a 25 per cent take up rate. ${ }^{93}$ Thus, rhetoric aside, the propensity of operatives to frequent those canteens established remained low, even during periods of food rationing. For example, between March 1947 to June 1948 the number of site canteens rose by some 40 per cent, yet overall only some twenty per cent of all building operatives obtained a main meal from them. It was noted that even "on jobs where the food is good and moderate in price there is often great difficulty in getting sufficient men to take the meal to ensure the economic success of the venture." 94

Indeed, setting aside the immediate post-war furore, the campaign to improve site facilities was not one that held center-stage for any great length of time, even amongst union delegates (where the commitment to those values 
of traditional respectability remained strongest). Through the 1950s the issue of poor amenities failed to make the NFBTO's conference agenda as a motion for debate. ${ }^{95}$ Was this because facilities noticeably improved with the introduction of statutory regulation and industry agreed codes? In part yes, but generally welfare standards continued to vary notably. That for washing accommodation remained "generally low"; and even when exemplary provision was made, most site operatives-including numbers of skilled workers-failed to use it. Nor did the quality of messrooms change significantly over the next decade. On smaller sites they were "often shabby, badly equipped and difficult to keep to any reasonable standard of cleanliness." Similarly, reported the Chief Inspector of Factories, while a "reasonable standard" of sanitary arrangements "may be found on larger sites", on smaller or rural sites they were frequently "inadequate and poorly maintained." building unions accepted that, like "many other hard-won advantages and rights, full observance of the welfare code depends to a great degree upon the keenness and loyalty of the men on the job." ${ }^{197}$ Judged by these criteria operative priorities, and the cultural imperatives that underpinned them, lay elsewhere.

Construction, more through its workplace culture than any exceptional physical constraints, continued to lose ground to other industries. Standards enshrined as being "improving" twenty years before, were by the 1960s, when the industry was again being subjected to the rhetoric of modernization, condemned by outsiders as being "medieval". "To be talking about buckets and trenches in 1963 is really terrible," argued Vic Feather (General Secretary, TUC), referring to the best practice sanitary arrangements sanctified by the 1948 code; but "to be satisfied with the standards you accept on building sites is, it seems to me, going back to the middle ages." 98 Yet the unions' shopping list of demands was of a more recent genre: the introduction of national pension and sickness schemes, as well as improvements to physical welfare and guaranteed time payments. "There is no doubt that the real advances we must make in this decade are within the field of the so-called fringe benefits," it was argued. ${ }^{99}$ Certainly the industry, comparatively, was deficient in this area at the beginning of the decade. By 1970 this was no longer the case. Amongst operatives, as opposed to union activists, however, such preoccupations remained of direct interest to a minority only. When asked what one change would make building a more attractive job, 39 per cent opted for more pay, and 25 per cent for better working conditions, but only 8 per cent for improved welfare and fringe benefits. ${ }^{100}$

Indeed only one welfare issue actively engaged operatives during the 1960s. Ironically it, too, had its roots in the "modernizing" processes designed to improve the status of building workers by cutting working hours and increasing pay. Union negotiators, however, accepted quid pro quo a long-standing employers' demand to control "the loss of working time occasioned by abuses" of the tea breaks system. ${ }^{101}$ Morning and afternoon breaks without loss of pay, although customary, had never been formally incorporated into the working rules. Employers now insisted that these be unpaid. The union leadership thought this a "really trivial' concession against the overall settlement"--"the best that we ... have ever been able to negotiate." 102 It was, however, "very badly received by the rank and file." With employers determined "to improve site discipline", it was finally resolved that sites settle locally. In the interim, some employers 
sought outright abolition, while, on major projects particularly, local union officials organized marches, stoppages and "go slows" to "Leave Us the Cuppa". Clearly "the fuss made over something which had little significance" caught the NFBTO leadership largely off guard. Abolishing the tea break potently signified an attempt by employers to evade customary obligations. The reaction against this provides strong testament to the continuing romantically masculine authority of customary independence and workplace control: of a "lived" site mentality of "what we have we hold."103

\section{Understanding site culture}

Could it be that building employers-in not seeking to "molly-coddle" operatives - had a greater clarity of understanding of worker attitudes and priorities than did the building unions, reformers at large, or employers in other industries? Was theirs a relationship less clouded by a priori judgements of what operatives ought to want, as opposed to what they actually valued within the duality of workplace culture and the labor contract? ${ }^{104}$ The evidence suggests that building operatives placed little worth initially on the welfare "rewards" gained on their behalf. Familiarity-whether experienced directly or ingested secondhandalso underpinned operative attitudes. Overall, however, this proved more a force for conservative reinforcement than for further reform. Improved amenities-a taster of a "better" site lifestyle-neither bolstered demands for further provision nor added greatly to the value given to that already in place. Only in the long term could attitudinal change be observed within a site culture to reform continually judged atavistic by researchers, politicians and union officials alike.

Why were site operatives resistant to those "improvements" offered? On smaller sites especially improvements lacked substance. Whether you squatted over a 3 foot deep hole, or one six foot deep with a fresh covering of chloride of lime was for the most part immaterial; ${ }^{105}$ while eating outside might frequently be more agreeable than sitting in a dank, ill kept mess-hall. Nor was it built on resentment because a welfarist agenda with attached costs was imposed on operatives by employers. Improvements were union led; employers were less enthusiastic regarding implementation. We return, therefore, to how operatives viewed themselves, and their daily relationship with work on site. Union representatives understood that poor provision correlated directly to measures of self-perception: in their words, that operatives "underestimated" their "human value". And in truth, all-unions, employers and operatives-placed a devaluing price on human life on site (both economically and culturally). Yet this ignores the very positive interpretation placed on site life by operatives, of which "rudimentary" provision was an intrinsic constituent. Site existence might be harsh, uncertain and dangerous-not a future operatives immediately wanted for their sons-but it was also informal, manly and self-defining. "Roughness", in terms of physicality, remained a component part of a site culture that stretched across the skills divide. Hardship could be translated into "bravado", "enjoying" spartan provision signified a dominance over adversity and simpatico with the outdoor life. In other words, these were "the kinds of things that men did," and building operatives were seen to do them more frequently and better than most. Yet self-reliance also tapped directly into traditional male crafts' indepen- 
dence, and thus, too, into the attendant lifestyles of bricklayers' and plasters' laborers. Significantly, conditions of work, which previously had been an indicative barometer of workplace control, became less central to how operatives, through their unions, viewed their relationship with work under national collective bargaining. It survived mostly through the thetoric of site life, occasionally surfacing (notably in the issue of tea-breaks) to remind union leaders of its former importance. Generally, however, welfare improvements meshed uncertainly with site constructs: they remained antagonistically peripheral to the operative's understanding of workplace culture and their place in it.

Not all reform, however, was apathetically received. Operatives more readily valued "fringe benefits"- those enticements directly linked to money wagesthan amenity improvements. By the late 1960 s some large contractors especially were, as some had in the 1930s, again offering extra recruiting inducements (like additional holidays, sickness pay and service increments) beyond the standard negotiated through the NJCBI. The building unions bitterly opposed this: they valued such benefits more highly than did operatives, but viewed them a right, not a bonus. ${ }^{106}$ Indeed earlier responses to wet time insurance, and later to paid tea-breaks, aptly illustrate the fragility of accord that at times existed between operatives and unions, and the unions themselves. "Fringe", in terms of marginal value, carried extra meaning to building operatives: thus, indicatively, while the initial response to paid holidays was tepid, although warming through time, many still chose to ignore the "benefit" completely and took instead illegal, discounted cash payments because such values more readily married with their construct of a manly site life.

Department of International Studies

Clifton Lane

Nottingham NG11 8NS

England

\section{ENDNOTES}

NFTBTO Annual Conference Reports, NFBTE Annual Reports, the Operative Builder and The National Builder cited in this article are available at the Modern Records Centre, University of Warwick. My thanks to the staff at the Centre for their invaluable assistance.

1. Alan Fox, cited in Chris Wrigley (ed.), A History of Industrial Relations, 1914-1939 (Hemel Hampstead, 1987), 6.

2. Helen Jones, "Employers' Welfare Schemes and Industrial Relations in Inter-War Britain," Business History 25 (November, 1983): 61-75; Joseph Melling, "Employers, Industrial Welfare, and the Struggle for Work-Place Control in British Industry, 18801920," in Howard Gospel and Craig Littler (eds.), Managerial Strategies and Industrial Relations (London, 1983), 55-81; Tim Clayton, "Trade Unions, Employers and Industrial Relations in the British Motor Car Industry c. 1919-45," Business History 29 (July, 1987): 304-24; Robert Fitzgerald, "Employers' Labour Strategies, Industrial Welfare, and the Response to New Unionism at Bryant and May, 1888-1930," Business History 31 (April, 1989): 48-65. For more positive constructions of welfarism, see Colin Griffin, "Not Just a Case of Baths, Canteens and Rehabilitation Centres: The Second World War and the Recreational Provision of the Miners' Welfare Commission in Coalmining Communities," in Nick Hayes and Jeff Hill (eds.), 'Millions Like Us'? British Culture in the Second 
World War (Liverpool, 1999), 261-94; Howard Gospel, Markets, Firms and the Management of Labour in Modern Britain (Cambridge, 1992); Stephen Jones, "The Survival of Industrial Paternalism in the Cotton Districts: A View from the 1920s," Journal of Local and Regional Studies 7 (Summer, 1987): 1-13.

3. Peter Ackers, "On Paternalism: Seven Observations on the Uses and Abuses of the Concept in Industrial Relations, Past and Present," Historical Studies in Industrial Relations 5 (Spring, 1998): 182-5; Robert Fitzgerald, British Labour Management and Industrial Welfare 1846-1939 (London, 1988), 12-17.

4. Robert Currie, Industrial Politics (Oxford, 1979), 242; H. Jones, "Employers' Welfare Schemes," 70-1.

5. Annual Report of Chief Inspector of Factories 1941 (hereafter ARCIF), Cmd. 6397 (London, 1942), 9.

6. Chris Wrigley, "State intervention in industrial relations, 1939-45," in C. Wrigley (ed.), A History of British Industrial Relations, 1939-1979 (Cheltenham, 1996), 35.

7. John MacInnes, "Conjuring up Consultation: The Role and Extent of Joint Consultation in Post-War Private Manufacturing Industry," British Journal of Industrial Relations 23 (1985): 92-113.

8. W.S Hilton, Industrial Relations in Construction (London, 1968), 93, 97.

9. Linda Clarke, "The 'Peculiarity or Backwardness' of Building Production," Product of the Built Environment 6 (1983): 30; Building Operative, Nov./Dec. 1952, 236; Christopher Powell, The British Building Industry Since 1800 (London, 1996), 128.

10. David Hall, Cornerstone: a Study of Britain's Building Industry (London, 1948), 89.

11. Powell, British Building, 128.

12. Ferdynand Zweig, Productivity and Trade Unions (Oxford, 1951), 68; Norah Davis, "Attitudes to Work: A Field Study of Building Operatives," British Journal of Psychology 38 (March, 1948): 110-11, 130.

13. Building Operative, July 1948, 9.

14. Joshua Freeman, "Hardhats: Construction Workers, Manliness and the 1970 ProWar Demonstrations," Journal of Social History 26 (Summer, 1993): 727.

15. Ibid; Sonya Rose, Limited Livelihoods: gender and class in nineteenth century England (London, 1992).

16. Stephen Meyer, "Work, Play, and Power: Masculine Culture on the Automotive Shop Floor, 1930-1960," Men and Masculinity 2 (October, 1999): 117-19.

17. Steven Maynard, "Rough Work and Rugged Men: The Social Construction of Masculinity in Working-Class History," Labour/Le Travail, 23 (Spring, 1989): 162-6.

18. Jeffrey Riemer, Hard Hats: The Work World of Construction Workers (Beverley Hills, 1979), 44-67.

19. ARCIF 1922, Cmd. 1920 (London, 1923), 57; ARCIF 1943, Cmd 6563 (London, 1944), 34 . 
20. ARCIF 1950, Cmd 8445 (London, 1952), 188; Dennis Marsden, "In the Mill," in Brian Jackson, Working-Class Community (London, 1968), 72-3.

21. See, for example, Mass Observation, People in Production: An Enquiry into British War Production (Harmondsworth, 1942).

22. Alice Russell, The Growth of Occupational Welfare in Britain (Aldershot, 1991), xx, 85.

23. Gospel, Markets, 27-30, 165; Howard Gospel, "Employers and Managers: Organisation and Strategy 1914-39," in Wrigley, Industrial Relations, 1914-39, 178-80.

24. Davis, "Attitudes to Work," 130-1; V. L. Allen, "Incentives in the Building Industry," Economic Journal 62 (September, 1952): 601.

25. For descriptions and illustrations, see Ministry of Labour, Welfare Arrangements on Building Sites (London, 1951).

26. Paul Willis, "Shop floor culture, masculinity and the wage form," in John Clarke, Chas Critcher and Richard Johnson (eds.), Working-Class Culture: Studies in History and Theory (London, 1979), 196.

27. ARCIF 1940, Cmd. 6316 (London, 1941), 16-17.

28. National Federation of Building Trade Employers (hereafter NFBTE) Annual Report, 1940, 20; National Builder, July 1941, 227; NFBTE Annual Report 1941, 42.

29. National Federation of Building Trade Operatives (hereafter NFTBO) Annual Conference Report 1941, 86-7.

30. Building Operative, March 1948, 9-10.

31. NFBTO Annual Conference Report, 1967, 20.

32. For further discussion, see Nick Hayes, "Forcing Modernisation on the 'one remaining really backward industry': British Construction and the Politics of Progress and Ambiguous Assessment," Journal of European Economic History (forthcoming, 2001).

33. George Bain and Robert Price, Profiles of Union Growth (Cambridge, 1980), 63.

34. Janet Drucker, "The History of Construction Unions: the Process of Structural Change," Product of the Built Environment 1 (1980): 69-74; lan Boranston, Hugh Clegg and Malcolm Rimmer, Workplace and Union (London, 1975), 102-7.

35. NFBTO Annual Conference Report, 1930, 41.

36. Zweig, Productivity, 67, 72-3; Ministry of Works, Working Party Report on Building (London, 1950), 7.

37. Jonathan Zeitlin, "'Rank and Filism' in British Labour History: A Critique," International Review of Social History 34 (Part 1, 1989): 60.

38. Modern Records Centre (hereafter MRC), MSS 187, NJCBI mins, 12 Jan. 1928; Presidential Address, NFBTO Annual Conference Report, 1938, 13; NFBTE Annual Report, 1945, 5 . 
39. Stephen Jones, "Work, Leisure and the Political Economy of the Cotton Districts Between the Wars," Textile History 18 (Spring, 1987): 49-51; Chris Wrigley, "The Trade Unions Between the Wars," in Wrigley, Industrial Relations, 1914-1939, 101.

40. Stephen Jones, "Trade-Union Policy Between the Wars: The Case of Holidays with Pay in Britain," International Review of Social History, 31 (Part 1, 1986): 64; Russell, Occupational Welfare, $\mathrm{xx}$.

41. S. Jones, "Trade-Union Policy," 65.

42. Ibid, 48, 51-2, 57; MRC, MSS 187, NJCBI mins, 21 Jan. 1943; MRC, MSS 78/ ASW/3/1/51 (14), letter from Wolsencroft to McIntosh, 18 Feb. 1928.

43. President, NFBTE Annual Conference Report 1934, 98.

44. Ibid.

45. Ibid., 96 .

46. MRC, MSS 187, NJCBI mins, 21 Jan. 1943. Over two thirds of all employers, although mainly smaller in size, were non-federated.

47. Ibid..

48. NFBTO Annual Conference Report 1944 148-9.

49. NFBTO Annual Conference Report 1955, 81; National Builder, June 1949, 273; NFBTO Annual Conference Report 1956, 73.

50. NFBTO Annual Conference Report 1954, 56.

51. NFBTO Annual Conference Report 1964, 71; NFBTO Annual Conference Report $1952,143-4$.

52. Gordon Philips and Noel Whiteside, Casual Labour: The Unemployment Question in the Port Transport Industry 1880-1970 (Oxford, 1985), 249, 271-2.

53. Davis, "Attitudes to Work," 110, 126-8.

54. Richard Price, Masters, Unions and Men: work control in building and the rise of labour 1830-1914 (Cambridge, 1980), 113-4; MRC, MSS 78/BO/4/5/5, NFBTO, Interim Report on a Scheme for the Payment for Time Lost Through Inclement Weather, c. 1938; National Builder, August 1936, 9.

55. MRC, MSS 78/BO/4/5/5, Interim Report.

56. B.C. Roberts, Trades Union Government and Administration in Great Britain (Cambridge Massachusetts, 1956), 226-37, offers comparable figures for building union voting rates for national and district officer elections at between $1 / 4$ to $1 / 2$ of those for the wet time ballot.

57. NFBTO Annual Conference Report 1938, 71, 90-102.

58. Zweig, Productivity, 73.

59. Presidential Address, NFBTO Annual Conference Report 1939, 16.

60. Ibid., 130; W.S. Hilton, Foes to Tyranny (London, 1965), 263-4. 
61. Operative Builder, Nov. 1947, 5.

62. MOW, Working Party, 35.

63. Ministry of Labour and National Service, Factory Form 1892 (London, 1941), 1; ARCIF 1941, Cmd 6397, (London, 1942), 14; ARCIF 1945, Cmd. 6992 (London, 1946), 27. For a more critical assessment generally of industrial wartime provision, see Barbara Drake, Community Feeding in Wartime (Fabian Research Series Vol. 6, London, 1942-3), $13-14$.

64. MOW, Working Party, 35; Zweig, Productivity, 68-9; Hall, Cornerstone, 101-3.

65. 10.5 per cent at its best in 1924 and 30.2 per cent at its worst in 1932, Harry Richardson and Derek Aldcroft, Building in the British Economy between the Wars (London, 1968), 116-33, 232-3.

66. MOW, Working Party, 34. See also, Ministry of Works, The Placing and Management of Building Contracts (London, 1944), 24-6.

67. Ministry of Health, The Cost of House-Building: First Report of the Committee of Enquiry (London, 1948), 42; Ian Bowen, "Incentives and Output in the Building and Civil Engineering Industries," The Manchester School (May, 1947): 157; Allen, "Incentives," 604. For an overview, see Hayes, "Forcing Modernisation," and generally, Nick Tiratsoo and Jim Tomlinson, Industrial Efficiency and State Intervention: Labour 1939-51 (London, 1993).

68. MOW, Working Party, 34; NFBTE Annual Report 1947, 37-8; Zweig, Productivity, 110.

69. Richard Whipp, "'The Art of Good Management': Managerial Control of Work in the British Pottery Industry, 1900-1925," International Review of Social History 29 (Part 3, 1984): 379-80; S. Jones, "Work," 48-9.

70. Wrigley, Industrial Relations, 1914-39, 7; Factory Form 1892, 2.

71. NFBTO Annual Conference Report 1955, 127; Drucker, "Construction Unions," 71.

72. For example, see MRC, MSS 187, NJCBI mins, 22 March 1933, on extra payment demanded for working from unsecured ladders.

73. NFBTO Annual Conference Report 1956, 107.

74. Michael Roper, Masculinity and the British Organization Man since 1945 (Oxford, 1994), 106-7; H. Jones, “Employers' Welfare Schemes," 70-1; ARCIF 1948, Cmd 7839, (London, 1949), 2, 51; Building Operative, Nov.-Dec. 1962, 295.

75. Building Operative, March/April 1955, 108; NFBTO Annual Conference Report 1963, $76-7$.

76. Price, Masters, Unions and Men, 168-9. He notes that unusually the Swansea Masons even demanded sanitary provision. Hilton, Foes to Tyranny, 164.

77. Freeman, "Hardhats," 727; Maynard, "Rough Work," 162.

78. Raymond Postgate, The Builders' History (London, 1923), 26-8; Allan Flanders and Hugh Clegg, The System of Industrial Relations in Great Britain (Oxford, 1954), 266. 
79. MRC, MSS 78/BO/9/8, NFBTO (London District) Working Rule Agreement, 1920; MSS 78/BO/9/10, NFBTO (London District) Working Rule Agreement, 1937; MSS 78/ BO/9/14, NFBTO Working Rules of Worthing and District, 1919.

80. NFBTO Annual Conference Report 1947, 41.

81. Drucker, "Construction Unions," 73.

82. MRC, MSS 187, NJCBI mins, 8 June 1945; MSS 78/BO/9/7, Working Rules for Liverpool, 1929; Hugh Clegg, History of British Trades Unions Since 1889. Volume II, $1911-1933$ (Oxford, 1985), 375-6.

83. For example, NFBTO Annual Conference Report 1930, 31.

84. Hugh Clegg, A History of British Trades Since 1889. Volume III 1934-1951 (Oxford, 1994), 42-3.

85. Freeman, "Hardhats," 728-31

86. Ibid.; Johanna Burke, Working-Class Cultures in Britain 1890-1960 (London, 1994), $130-2$.

87. Davis, "Attitudes to Work," 111, 126-7; FM. Martin, "Some Aspects of Social Stratification," in D. V. Glass (ed.), Social Mobility in Britain (London, 1954), 68-79.

88. Davis, "Attitudes to Work," 127.

89. Allen, "Incentives," 600-1; Ferdynand Zweig, The British Worker (Harmondsworth, 1952), 96-105.

90. NFBTO Annual Conference Report 1946, 65.

91. NFBTO Annual Conference Report 1945, 75; Hayes, "Forcing Modernisation".

92. NFBTO Annual Conference Report 1946, 65 .

93. Ministry of Labour, Welfare Arrangements, 9.

94. Operative Builder, May 1948, 13-14, November 1948, 32a; MOW, Working Party, 35.

95. NFBTO Annual Conference Report 1963, 75.

96. ARCIF 1951, Cmd 8772 (London, 1953), 165-6; ARCIF, 1948, Cmd 7839 (London, 1949), 114; ARCIF, 1954, Cmd 9330 (London, 1955), 219; Ministry of Labour, Report on Safety and Health in the Building and Civil Engineering Industries 1954-1958, Cmnd 953 (London, 1960), 24.

97. Operative Builder, Nov./Dec. 1952, 235.

98. NFBTO Annual Conference Report 1963, 72. See National Builder, February 1948, 143, and Ministry of Works, Welfare Arrangements, for welfare codes operating.

99. NFBTO Annual Conference Report 1965, 96, 99.

100. Russell, Occupational Welfare, 124-5, 190-1; Geoffrey Thomas, Operatives in the Building Industry (London, 1968), 47-8. 
101. MRC, MSS 187, NJCBI mins (verbatim), 12 January 1961, 24, 28; MSS 187, NJCBI mins, 11 December 1945, 5; NFBTE Annual Report 1946, 34; NFBTE circular, reprinted in Operative Builder, July/August 1961, 180.

102. NFBTO Annual Conference Report 1961, 12.

103. NFBTE Annual Report 1961, 8-10; NFBTO Annual Conference Report 1962, 2-3; NFBTO Annual Conference Report 1963, 131; MRC, MSS 187, NJCBI mins (verbatim), 12 January 1961, 29; Operative Builder, July/August 1962, 180; Davis, "Attitudes to Work," 113.

104. Consider, for example, Patrick Joyce, "Refabricating labour history: or, from labour history to the history of labour," Labour History Review 62 (Summer, 1997): 147-52.

105. Ministry of Labour, Welfare Arrangements, 11-15.

106. NFBTO Annual Conference Report 1969, 78; Fitzgerald, British Labour Management, 150. 